\begin{tabular}{ll}
\hline \hline MINING AND METALLURGY INSTITUTE BOR & ISSN: 2334-8836 \\
& UDK: 622 \\
\hline \hline
\end{tabular}

UDK: $622.271: 622.68(045)=111$

DOI:10.5937/MMEB1403001M

Miroslava Maksimović, Mile Bugarin ${ }^{*}, Z^{\prime}$ Zoran Stevanović, Vladan Marinković

\title{
TECHNOGENIC DEPOSIT IN THE AREA OF THE OLD FLOTATION TAILING DUMP IN BOR (FIELD 1 AND FIELD 2)
}

\begin{abstract}
The copper ore mining in Bor was started at the beginning of the twentieth century. Parallel to this, the ore smelting was carried out in the first period. After construction of the Flotation Plant (1934), the ore dressing was performed and obtaining the concentrate of copper and precious metals. Until the 60's of the last century, the ore processing, obtained from exploitation from the copper deposits Bor (the Old Open Pit and underground mine Jama Bor), was carried out. After this period of ore obtained from the Bor mine, the ore from the deposit Lipa, Cerovo (Mali Krivelj) was also processed. Technogenic waste offlotation was obtained as by-product of this process by flotation that was disposed from 1934 to 1980 in the area of the Old Flotation Tailing Dump in Bor (Field 1 and Field 2).

Based on the previous geological explorations in the mentioned zone, the increased copper contents were indicated in the subject area. The implementation of detailed geological explorations would evaluate the potentiality of the area, in order to review the possibilities of raw material leaching, as well as solving a serious environmental problem in the center of the town of Bor.
\end{abstract}

Keywords: tailing dump, technogenic formations, copper ore mining, open pit

\section{INTRODUCTION}

Technogenic copper deposit the "Old Bor Flotation Tailing Dump" is located in the industrial circle of the Mining and Metallurgy basin (RTB), or in the town of Bor. Bor is usually a typical mining town, founded by the mine (Figures 1 and 2).

The largest amount of technogenic formations separated in the immediate vicinity of the Bor and Krivelj mines in an area of over $4 \mathrm{~km}^{2}$. They are presented by creations that occurred by exploitation of mineral deposits of copper (overburden) and mineral processing (flotation tailings) Figure 2 shows the old flotation tailing dump in Bor.
For the relief of the terrain, in wider area of Bor, a significant impact had intensive volcanic activity (during the late Mesozoic and Cenozoic), which is accompanied by strong tectonic movements.

However, the formation of current look of relief was influenced by the economic activity in the mineral-raw material complex.

The processes of exploitation, preparation, and processing of ore in Bor and its surroundings, caused the changes of relief and formation of some inverse morphological forms, such as the open pits and landfills (rock overburden, mining waste, flotation tailings, smelter slags, calcined pyrite).

\footnotetext{
${ }^{*}$ Mining and Metallurgy Institute Bor

** This work is the result of the Project TR37001 "The Impact of Mining Waste from RTB Bor on the Pollution of Surrounding Water Systems with the Proposal of Measures and Procedures for Reduction Harmful Effects on the Environment", funded by the Ministry of Education, Science and Technological Development of the Republic of Serbia
} 


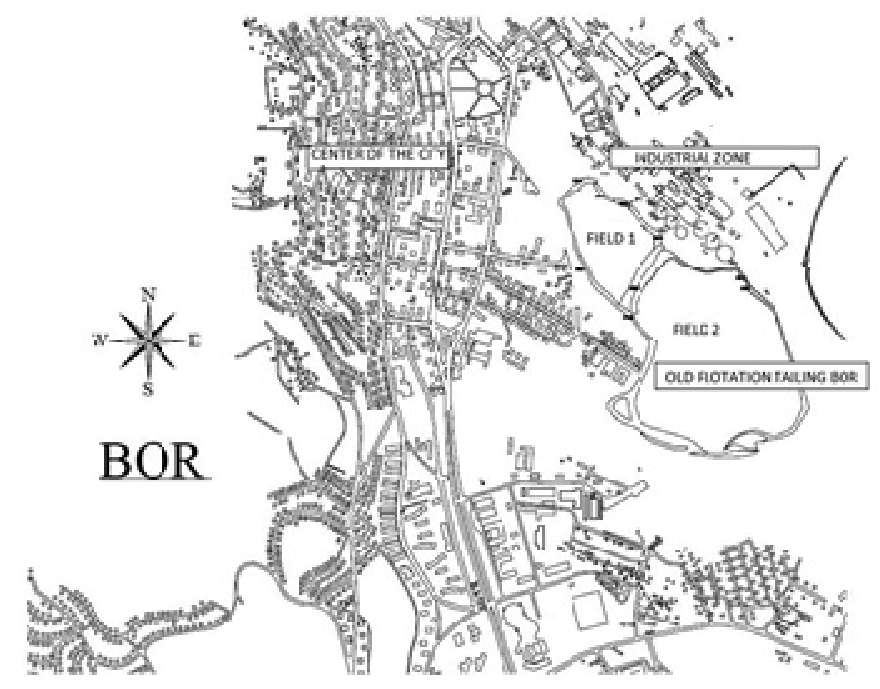

Figure 1 The spatial position of the old flotation tailing dump in relation to the town center

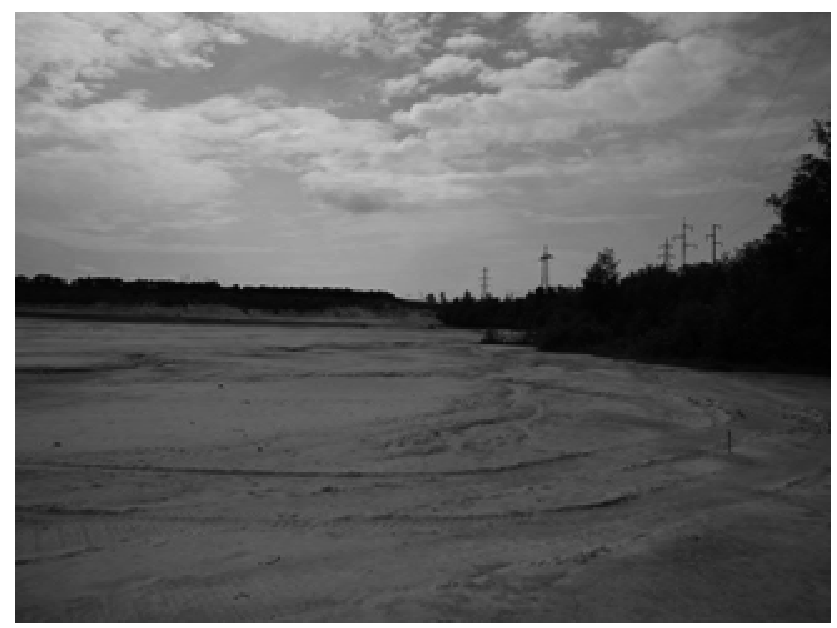

Figure 2 The Old flotation tailing dump in Bor (May 2011)

It should be emphasized that the human activity has significantly influenced the formation of the current look of relief. The exploitation of copper deposits (the old open pit in Bor and open pit "Veliki Krivelj") caused the changes to the natural environment, for now, primarily in terms of the degradation of the natural terrain, creating inverted form, in the form of depression (open pit mining), on one hand, and on the other side of the rise of the accumulated material of rock overburden (waste rock) as well as flotation tailings especially dangerous to the natural environment.

The starting point for a preliminary evaluation of the potentials was the results of previous explorations that were collected, analyzed and synthesized. Preliminary evaluation of the potentials was performed based on the results of completed geological explorations, which were conducted by the Mine Geological Department of the Copper Mine Bor and Bureau of Geology and Mining and Metallurgy Institute Bor (old name: Copper Institute Bor) in the period 1947-2010, and based on data from the old documentation of 


\section{GEOLOGICAL STRUCTURE OF THE OLD FLOTATION TAILING DUMP IN BOR (field 1 and field 2)}

the mine dating from 1909 until 1941. Based on the applied methodology of previous explorations, it can be concluded that the deposition of tailings from the flotation used the former bed of the Bor stream, so that today the river bed is filled and the ground is leveled. According to the previous studies, tailings disposal in the research area started by the French, and during the Second World War, the Germans continued. After the Second World War deposition of tailings in the area in question was carried out by $1980^{\prime}$. Starting from the results of previous exploration works, it can be concluded that the degree of exploration of the research area is low. Detailed geological explorations were carried out by the system of exploration drilling in the Field 1. Problems that should be dealt with the implementation of exploration works is reflected in the following:

- Define the geological characteristics, structural complex, contour and shape the physical and mechanical properties of paleorelief (the riverbed of the Bor stream) and tailings, then determine the quality, and make technological preparations and testing capabilities of application the technogenic raw materials.

- Analyze the factors and indicators of geological and economic evaluation characteristic of detailed geological studies (metallogenic geological, mining, technology, market, regional and socio-economic factors and corresponding indicators) on the basis of which the evaluation of potentials of exploration area, the classification and categorization of mineral materials.

- After the potentiality evaluation based on the results obtained from the detailed implementation of applied exploration, and possible mining activities, the reclamation and remediation will be carried out in the subject area.
Previous geological explorations, especially on geological maps, clearly indicate that the wider environment Bora, and therefore the wider environment of the old flotation tailings in Bor, are mostly built from volcanic - pyroclastic and sedimentary rocks of the Cretaceous age. On smaller scale, they are represented by granites and the Palaeozoic rocks of Jurassic, Tertiary and Quaternary age. Greater distribution of Cretaceous formations, including the deposition of the copper mineralization, the most significant are hydrothermally altered volcanic rocks of the Cretaceous age.

The space of the old Flotation Tailing Dump (Field 1 and Field 2) is a specific in maby ways. Geological characteristics of technogenic raw materials of the old flotation tailing dump (Field 1 and Field 2), conditioned by the immediate background on which they are deposited, and the way formation the landfill. The immediate surface of the landfill is mostly of the geogenic creations (the Bor conglomerates, volcanoclastic rocks and alluvial deposits. For tailings disposal from the flotation, the former bed of the Bor stream is used, so that today the entire riverbed is filled and the ground is leveled. Tailing dump is located close to the existing facilities of RTB, primarily the Bor Flotation Plant. Based on the available documentation on previous explorations, it can be concluded that the former bed of the Bor stream is much carved and that the stream was steep.

Disposal of tailings was carried out in this way that the initial dam was formed on a downstream part of the stream of larger particles of sand and surface overburden, and then the entire length of the stream was used for tailings disposal. Disposal of tailings began by French, in the northern part of the Bor stream, near the train station, since 1934 until 1941, when the Germans continued to 
deposit tailings. The Germans continued to deposit tailings in the lower southern parts of the Bor stream. After the war, disposal of tailings was continued so that the entire riverbed was filled with tailings, with the trained field first pitch has been leveled at an approximate elevation of 360 its first field in the field. Field 1 has an oval shape. Dimension of long axis (NW - SE) was about 400 $\mathrm{m}$ and shorter (SW - NE), about 300 meters. South of Field 1, downstream at about 600 $\mathrm{m}$, the dam was formed by flotation of sand. Width of Dam 1 is approximately $30 \mathrm{~m}$. At about $800 \mathrm{~m}$ from the dam, downstream one dam is formed, the second dam. Between Dams 1 and 2 dams the flotation tailings was deposited so that the coarsest particles are separated and deposited on the banks of the Bor streams and dams, and the central part of the area between the dams filled with finer flotation tailing. In the area between the Dam and the Dam , the Field 2 was formed in terrain on the field 2 that is flattened at an approximate elevation of $368 \mathrm{~m}$. Field 2 has an elliptical shape. Dimension long axis (NW - SE) was about $800 \mathrm{~m}$ and shorter (SW - NE), about $600 \mathrm{~m}$. The entire area (Field 1 and Field 2) has an elliptical shape, which includes surfaces of about $1 \mathrm{~km}^{2}$. Technogenic copper deposit the Old Flotation Tailing Dump in Bor, was the result of ore enrich-ment obtained by exploitation the old open pit and underground mining. For many years the flotation tailings disposal was done in the form of sludge, dust and sand. Flotation concentration of minerals due to mine-ralogical and petrologic characteristics of ores and useful minerals, as well as due to the imperfections of technological process, $85 \%$ separates copper in concentrate, with the remainder allocated in the flotation tailings. Similarly with the other useful components, the percentage share of beneficial components separated in the concentrate or the tailings depending on their utilization of applied technological process of enrichment.

For the space the old flotation tailings in Bor, tectonics is important because it actu- ally works on contemporary creations that were exposed by tectonic forces acting in geological time. However, it should provide a brief overview of the fissure tectonics in geogenic surface of deposits. The most striking structure in the immediate vicinity of the exploration area is the Bor fault. The Bor fault is actually a fissure (rupture) zone, the width of which reaches $30-40 \mathrm{~m}$, with milonitic zone from 4 to $8 \mathrm{~m}$ thick. The main structural directions are from the Bor deposit to the north, the present system of smaller sub-parallel faults along the eastern rim of the Bor metallogenic zone. By the morphostructural analysis of the area (Petkovic, 1984), it was found that the large Bor fault can be traced to the fault Veliki Pek. It presents a complex zone of breaking, formed in the post mineral period. A steep decline $\left(75-80^{\circ}\right)$ to the southwest and has left transcurrent to the left reverse movement. These structures indicate some premineralization movement and they are spatially found only in the eastern edge of TMC.

\section{REVIEW OF PREVIOUS EXPLORATIONS}

Evidence of mining activities in the area of the Bor metallogenic zone dated back to the 6th millennium ago (Rudna Glava), followed by the ancient antic and Roman periods. Modern geological explorations in Eastern Serbia begun in the late 19th century and in 1903' an adit cut off the ore body Coka Dulkan in Bor. Since then, mining and geological explorations in the Bor copper mineralization have been intensified.

The wider area of exploration field of the Old Bor tailing dump is the surrounding of Bor, or an area that was previously largely treated as the wider environment of Bor. Geological data on this field are found in the works by Žujović (1889, 1893, 1900), Antula (1904), Lazarevic (1909, 1910), Cvijic (1904), V. Petkovic (1935), Ilic and Simic (1949), Antonijevic (1957, 1959), and M. and F. Drovenik (1956), M. Drovenik 
(1953, 1959, 1961, 1966, 1968, 1983), M. Drovenik, Antonijević I. et al. (1962, 1967). The explorations related to study of tailing dumps and slag landfills and their use as technogenic raw materials started at the beginning of the sixties and the interruption lasts until today. It was only at the beginning of this century, in terms of less mining, paying greater attention to tailing dump as potential areas for finding the economically interesting concentrations of copper and other useful components. It contributes to steady increase in the price of copper and precious metals lately.

In wider area of exploration area the Old Flotation Tailing Dump (Field 1 and Field 2 ), in the area of mine field Bor, extensive explorations were conducted. Explorations in the postwar period were carried out from June in 1961 to the end of January 1962, with the applied geological works, and mining exploration works (exploration drilling). Drilling was carried out in the period from 1961 to 1962. Exploration drilling is included in the part of the research area, the so-called Field 1, wherein drilled 87 shallow drill holes per square network of 40x40 m. The drill hole length was $10 \mathrm{~m}$, and only a small number have length of $30 \mathrm{~m}$. The per- centage of removed core was about $100 \%$ [VII]. The drill holes were analyzed for copper, and total oxide, and sulfur. Analyses of the associated beneficial and detrimental components were also carried out.

Exploitation of the Bor deposit, since the beginning of the last century, caught on 26 ore bodies - hole and surface mine (largely at the same time. Thereby was obtained the total of 146270000 tons of ore from which copper was extracted 2,437 million tons of metal copper, $139140 \mathrm{~kg}, 415000 \mathrm{~kg}$ of gold and silver. It was also excavated and 436,2 million tons of barren mass of overburden and associated rocks [I].

The exploitation of copper deposits, the old open pit in Bor (Figure 3), and later by the underground mining and enrichment of ore and concentrate obtained in the Bor Flotation Plant, have caused the changes of paleorelief in terms of degradation the natural terrain, creating elevations of accumulated material of tailings. Metallur-gical treatment of concentrates resulted in formation of slag. The largest amount of slag is disposed at the site between the open pit ore body "H" and former Pralište where the workshops of the old open pit are located, and it is the location known as the "Slag Depot - 1".

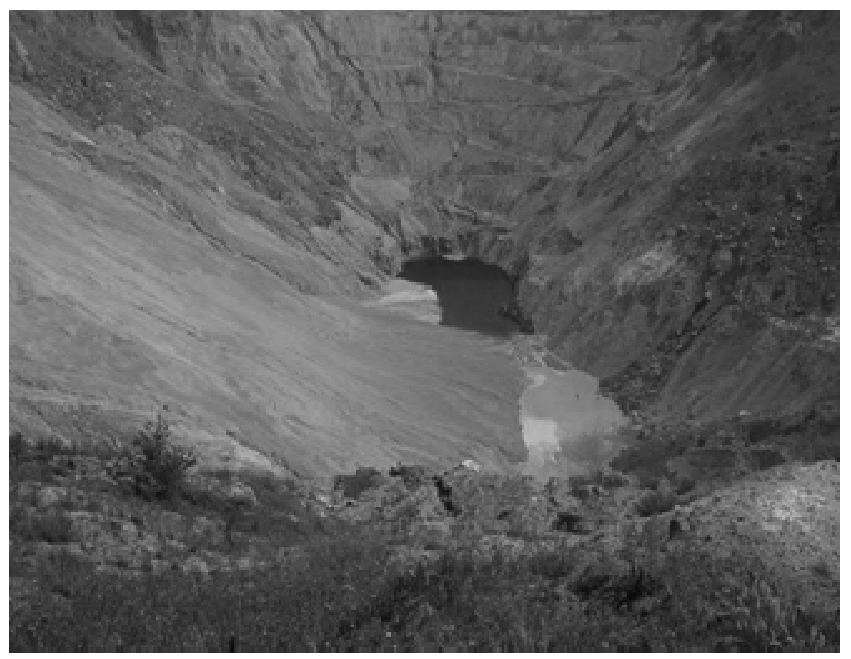

Figure 3 The old open pit Bor, Bor (August 2005) 
Depending on the technology that was used in the exploitation phase of metallurgical melting process, it was produced in the slag, as well as to the characteristics of the ore, copper concentrate and flux, the technogenic waste was created, very different both physically and mineralogically, and chemical characteristics. All slag formed in different time periods were delayed at several sites, and in some locations were carried out and move due to mining activities at the opening and expansion of open pit mines (the old open pit mine and open pit ore body "H").

\section{DESIGN SOLUTIONS FOR DETAILED GEOLOGICAL SURVEY OF APPLIED GEOLOGICAL EXPLORATIONS}

Based on the analysis and synthesis of current research and literature data, are defined by the concept and methodology of research in the future. Detailed applied geological explorations will be carried out with the aim of finding the additional amount of copper from technogenic deposits to increase the mineral - raw materials of "RBB", and therefore increase the amount of ore that will be processed. Detailed geological explorations in the area of the old flotation tailings are focused on gradual, systematic and comprehensive research and testing in this area and finding economically interesting amounts of secondary raw material. The overall geological explorations are subordinated and adapted geology - metal - terrain conditions, the degree of its exploration, current issues and goals of exploration.

The main objective is to carry out detailed geological studies to determine the data needed for the study on ore reserves , which is necessary for future mine design , and obtaining the relevant data for the reclamation and remediation of the area which is located in the town of Bor. Geological investigations in the coming period applied to complex research methods, which in cludes the following activities: surveying works, geological work, drilling, field testing, laboratory and technological research in the laboratory and pilot plant scale. Geological survey will be followed by geological mapping and sampling, core drilling to investigate the quality and quantity of mineral resources: samples will be taken for mineralogical and petrological studies; soil testing will be performed in order to assess the possibilities for exploitation of mineral resources. The quality testing involves taking a sample of mineral raw materials for chemical and technological studies. Exploration carried out to define the geological structure and geological characteristics of the research area, and confirm the results of investigations of mineral resources obtained earlier research works.

\section{CONCLUSION}

The subject property is located in the town of Bor, near the Bor Flotation Plant. Based on previous geological studies, the copper mineralization is indicated in the said zone which would be explored by realization of geological works to the level B and C1 category reserves, and determine the quality of mineral resources, and the content of copper, gold, silver and other useful but also harmful components.

The main objective of geological research area the Old Bor tailing dump is to be in accordance with the data collected on the results of previous research to make the selection of optimal design solutions (type and scope of work) for the upcoming research for the purpose of finding copper and associated useful components in technogenic dumps raw materials. Density of exploration works depends on the achieved results of which depends on further explorations. Based on exploration study, the potentiality of study area was carried out. The implementation of detailed applied exploration in the form of research papers, it is expected to 


\section{REFERENCES}

be reliably determine the characteristics of technogenic deposits (type and volume of works), the quality of mineral resources, determine reserves to levels $\mathrm{B}$ and $\mathrm{C} 1$ categories. Based on the exploration results rated to the geological, technical - exploitation, technological, market, regional and socialeconomic factors and the corresponding data research. The economic importance of exploration the technogenic raw materials, in the old flotation tailings in Bor, the market value of useful components that can be drawn from them, favorable regional factors, environmental protection through subsequent reclamation and remediation research area, are of course direct reasons that justify the projected performance of geological exploration. Geological exploration of the research area and finding economically interesting concentrations of copper and associated minerals (gold, silver and molybdenum) will be definitely found as very significant reflection in terms of geological and economic efficiency of the presented geological exploration.

Certainly it can be said that the projected geological survey research area the Old flotation tailing dump as the general socio - economic trends and needs, as well as long-term planning and development orientation of RTB, the town of Bor and the Republic of Serbia. Therefore, it is with this aspect can be concluded that the importance and economic feasibility of the projected research task beyond doubt, which is the direct reason for the current study consistently implemented.

The obtained results of detailed geological explorations would be synthesized through development an elaborate on completed geological explorations and Elaborate on mineral reserves. Explorations would be accompanied with development of appropriate graphic documentation, periodic reports, and Elaborate on completed geological explorations.
[1] Maksimović M., Nikolić K., et al., Elaborate on Reserves of the Copper Deposit Bor (Ore Bodies "Brezanik", "Tilva Roš" and "P2A"), state on 31/12/2004-textual part, Fund of Technical Documentation, Geology Department, MMI, Bor; 2005, p.144;

[2] Maksimović M.: Project of Detailed Geological Explorations of Copper and Other Useful Components in the Area of the Old Flotation Tailing Dump in Bor (Field 1 and Field 2), in 2011/12, Fund of Technical Documentation, Geology Department, MMI Bor; 2011, p.44;

[3] Maksimović M.: Project of Explorations and Testing the Flotation Tailing Dumps and Open Pit Waste Dumps Bor, in the Area of Inactive Ecological Exploitation Field Related to the Activities of Remediation by the World Bank, Fund of Technical Documentation, Geology Department, MMI Bor; 2011, p. 55;

[4] Maksimović M.: Project of Geological-Ecological Exploration and Testing Within the Endangered Ecological Zone - Tailing Dumps in Bor (Dam 2), Fund of Technical Documentation, Geology Department, MMI Bor; 2012, p. 20;

[5] Maksimović M.: Elaborate on Realized Geological Explorations and Testing the Flotation Tailing Dumps and Open Pit Waste Dumps Bor, in the Area of Inactive Ecological Exploitation Field Related to the Activities of Remediation by the World Bank, in the period 2011/12, Fund of Technical Documentation, Geology Department, MMI Bor; 2012, p. 83;

[6] Maksimovic M.: Applied Project of Detailed Geological Exploration the Technogenic Mineral Resources in the 
Area of the Old Flotation Tailings DumpBor (Field 1 and Field 2), from 2014 to 2017, Fund of Technical Documentation, Geology Department, MMI Bor; 2014, p.55;

[7] Stevanovic O., Study of Copper Reserves in the Flotation Tailings textual part, Fund of Technical Documentation, Geology Department, MMI Bor; 1963, p.106.

[8] M. Maksimović, M. Jovanović, G. Pačkovski, V. Marinković: Preliminary Geological Exploration Works in
Order to the Environmental Management in the Area of Inactive Ecological Mining Field, Mining and Metallurgy Engineering Bor, 2/2014, pp. 1-6.

[9] M. Pavlović, N. Vušović, M. Maksimović, R. Rajković: Basic Principles of Development and use a Digital Geomodel for Design the Open Pit in the Example of Quartz and Sandy Clay Deposit "Bošnjane" - Serbia, Mining and Metallurgy Engineering Bor, 2/2014, pp. 97-106. 


\begin{tabular}{ll}
\hline \hline INSTITUT ZA RUDARSTVO I METALURGIJU BOR & ISSN: 2334-8836 \\
& UDK: 622 \\
\hline \hline
\end{tabular}

\title{
TEHNOGENO LEŽIŠTE NA PROSTORU STAROG FLOTACIJSKOG JALOVIŠTA BOR (POLJE 1 I POLJE 2) ${ }^{* *}$
}

\begin{abstract}
Izvod
Početkom dvadesetog veka započeta je eksploatacija rude bakra u Boru. Paralelno sa tim vršeno je, u prvom periodu, topljenje rude. Nakon izgradnje flotacijskih pogona (1934. godine) vršeno je obogaćivanje rude, i dobijanje koncetrata bakra i plemenitih metala. Do 60-tih godina prošlog veka u Flotaciji Bor vršena je priprema rude dobijena eksploatacijom iz ležišta bakra Bor (stari površinski kop i Jama Bor). Nakon tog perioda pripreme rude dobijene iz borskog rudnika, priprema se, i ruda iz ležišta: Lipa, Cerovo (M. Krivelj). Kao nus-produkt ovog procesa dobijen je tehnogeni otpad flotiranja koji je deponovan od 1934. godine do 1980. godine, na prostoru Starog flotacijskog Jalovišta u Boru (Polje 1 i polje 2).

Na bazi dosadašnjih geoloških istraživanja u pomenutoj zoni, indicirani su povišeni sadržaji bakra na predmetnom prostoru. Realizacijom detaljnih geoloških istraživanja ocenila bi se potencijalnost prostora, cilju sagledavanje mogućnosti luženja sirovine, kao i rešavanje velikog ekološkog problema u samom centru grada Bora.
\end{abstract}

Ključne reči: jalovište, tehnogene tvorevine, eksploatacije rude bakra, površinski kop

\section{UVOD}

Tehnogeno ležište bakra "Staro borsko flotacijsko jalovište" nalazi se u industrijskom krugu «Rudarsko-topioničarskog basena» (RTB), odnosno u samom gradu Boru. Bor je inače tipični rudarski grad, nastao uz rudnik. (slike 1 i 2).

Najveća količina tehnogenih tvorevina izdvojena je u neposrednoj okolini borskog i kriveljskog rudnika, na površini od preko $4 \mathrm{~km}^{2}$. Predstavljene su tvorevinama koje su nastale eksploatacijom rudnih ležišta bakra (raskrivka) i pripremom mineralnih sirovina (flotacijska jalovišta). Na slici 2 prikazano je staro flotacijsko jalovište u gradu Boru.
Na reljef terena, u širem području Bora, znatan uticaj imala je intenzivna vulkanska aktivnost (krajem mezozoika i tokom kenozoika), koja je praćena snažnim tektonskim pokretima.

Međutim, na formiranje sadašnjeg izgleda reljefa uticala je i privredna aktivnost u mineralno-sirovinskom privrednom kompleksu. Procesi eksploatacije, pripreme, i prerade rude u Boru i okolini, uslovili su promene reljefa $i$ nastajanje pojedinih inverznih morfoloških oblika, kao što su površinski kopovi i deponije (stenske otkrivke, rudničke jalovine, flotacijske jalovine, topioničke šljake, piritnih ogoretina).

\footnotetext{
${ }_{* *}^{*}$ Institut za rudarstvo i metalurgiju Bor

Ovaj rad je rezultat Projekta br TR: 37001 „Uticaj rudarskog otpada iz RTB Bor na zagađenje vodotokova, sa predlogom mera i postupaka za smanjenje štetnog dejstva na životnu sredinu", finansiranog od strane Ministarstva prosvete, nauke i tehnološkog razvoja Republike Srbije.
} 


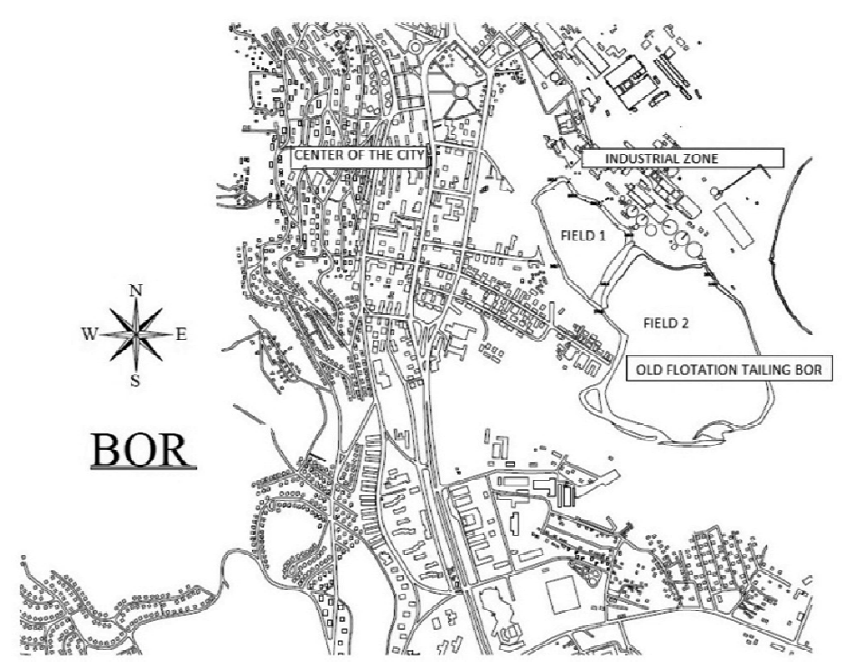

SI. 1. Prostorni položaj starog flotacijskog jalovišta u odnosu na gradsko jezgro

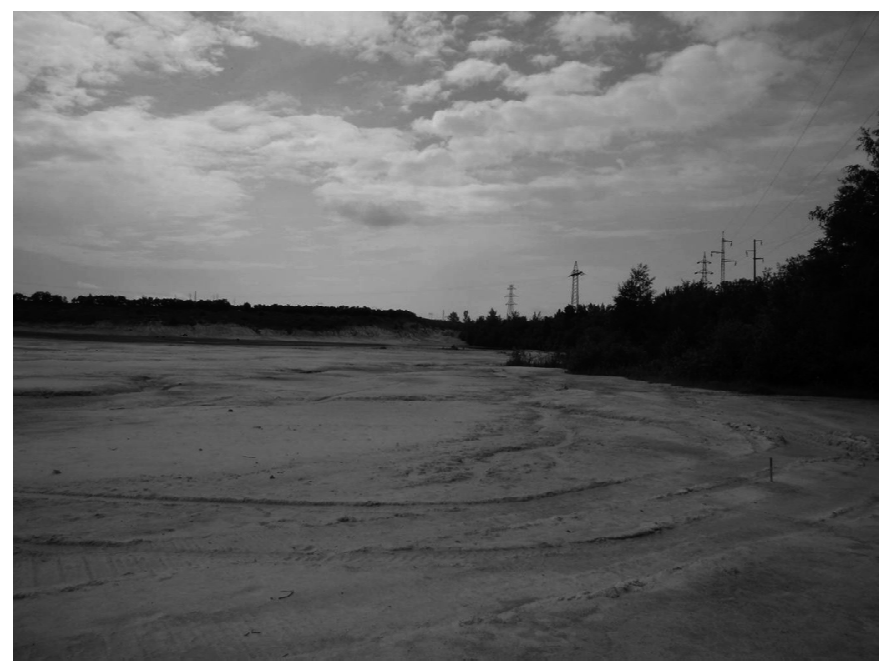

SI. 2. Staro flotacijsko jalovište u Boru (maj 2011.)

Posebno treba naglasiti da je i ljudska aktivnost znatno uticala na formiranje sadašnjeg izgleda reljefa. Eksploatacija ležišta bakra (stari površinski kop u Boru i površinski kop „Veliki Krivelj“) uslovila je izmene prirodnog ambijenta, za sada prvenstveno u smislu degradacije prirodnog reljefa, uz stvaranje inverznih oblika, u vidu depresije (površinski kopovi), s jedne strane, i sa druge strane uzvišenja od nagomilanih materijala stenske jalovine (otkrivke), kao i flotacijske jalovine posebno opasne po prirodni ambijent.

Polazna osnova za preliminarnu ocenu potencijalnosti, bili su rezultati ranijh istraživanja, koji su prikupljeni, analizirani i sintetizovani. Preliminarna ocena potencijalnosti je urađena na osnovu rezultata izvršenih geoloških istraživanja, koja su izvršili: rudnička geološka služba Rudnika bakra Bor i Biroa za geologiju, i Institut za rudarstvo i metalurgiju Bor (stari naziv: Institut za bakar Bor), u periodu 1947-2010. god., kao i na osnovu podataka stare doku- 


\section{GEOLOŠKA GRAĐA STAROG FLOTACIJSKOG JALOVIŠTA U BORU (Polje 1 i Polje 2)}

mentacije rudnika iz perioda od 1909. godine do 1941. godine. Polazeći od primenjene metodologije dosadašnjih istraživanja, može se zaključiti da je za deponovanje jalovine iz flotacije korišćeno nekadašnje korito Borskog potoka, tako da je danas čitavo korito ispunjeno, a teren iznivelisan. Prema podacima dosadašnjih istraživanja, deponovanje jalovine na istražnom prostoru započeli su Francuzi, a za vreme Drugog svetskog rata nastavili Nemci. Posle Drugog Svetskog rata deponovanje jalovine na predmetnom prostoru vršeno je do 1980 . godine. Polazeći od rezultata dosadašnjih istraživanja, može se zaključiti da je stepen istraženosti na istražnom prostoru nizak. Detaljna geološka istraživanja, sistemom istražnog bušenja, vršena su u na polju 1 . Problematika koju treba rešavati realizacijom istražnih radova ogleda se u sledećem:

- Definisati geološke karakteristike, strukturni sklop, konturu i oblik, fizičkomehaničke karakteristike paleo reljefa (korito Borskog potoka), i samog jalovišta, zatim odrediti kvalitet, i izvršiti tehnološka ispitivanja mogućnosti pripreme i primene, tehnogene sirovine.

- Analizirati faktore i pokazatelje geološko-ekonomske ocene karakteristične za detaljna geološka istraživanja (metalogenetske, geološke, rudarske, tehnološke, tržišne, regionalne i socijalno-ekonomske faktore i odgovarajuće pokazatelje) na osnovu kojih se vrši ocena potencijalnosti istražnog prostora, klasifikacija i kategorizacija ležišta mineralnih sirovina.

- Nakon izvršene ocene potencijalnosti na osnovu rezultata dobijenih realizacijom primenjenih detaljnih istraživanja, i moguće rudarske aktivnosti, izvršila bi se sanacija i rekultivacija na predmetnom prostoru.
Dosadašnja geološka istraživanja, posebno rad na geološkim kartama, nedvosmisleno ukazuju da je šira okolina Bora, a samim tim i šire okoli starog flotacijskog jalovišta u Boru, pretežno izgrađena od vulkansko-piroklastičnih i sedimentnih stena kredne starosti. U manjem obimu zastupljeni su paleozojski graniti i stene jurske, tercijerne i kvartarne starosti. Veće rasprostranjenje imaju kredne tvorevine, među kojima za depoziciju bakrove mineralizacije najveći značaj imaju hidrotermalno izmenjene vulkanske stene kredne starosti.

Prostor starog flotacijskog jalovišta (Polje 1 i Polje 2), je po mnogo čemu specifičan. Geološke karakteristike tehnogenog sirovine starog flotacijskog jalovišta (Polje 1 i Polje 2), uslovljene su pre svega neposrednom podlogom na kojoj su deponovane, kao i načinom obrazovanja deponije. Neposredna podloga deponije su najvećim delom geogene tvorevine (borski konglomerati, vulkanoklastične stene i aluvijalni nanos. Za deponovanje jalovine iz flotacije, je poslužilo nekadašnje korito Borskog potoka, tako da je danas čitavo korito ispunjeno, a teren iznivelisan. Jalovište se nalazi neposredno uz postojeće objekte RTB-a, u prvom redu Borske flotacije. Na osnovu dostupne dokumentacije o dosadašnjim istraživanjima može se zaključiti da je nekadašnje korito Borskog potoka znatno usečeno, $\mathrm{i}$ da su obale potoka bile strme.

Deponovanje flotacijske jalovine vršeno je na taj način, što se na nizvodnom delu potoka formirala inicijalna brana od krupnijih čestica peska i površinske raskrivke, a onda je celom dužinom potoka vršeno odlaganje flotacijske jalovine. Deponovanje flotacijske jalovine započeli su Francuzi, u severnom delu Borskog potoka, u neposrednoj blizini železničke stanice, od 1934. godine pa sve do 1941. godine, kada su 
Nemci nastavili sa deponovanjem flotacijske jalovine. Nemci su sa deponovanjem jalovine nastavili u nižim južnim delovima Borskog potoka. Posle rata nastavljeno je deponovanje jalovine, tako da je čitavo korito ispunjeno flotacijskom jalovinom, pri čemu je obrazovano Polje 1. Teren je poravnjan na približnoj koti $360 \mathrm{~m}$ u Polju 1. U planu, Polje 1 ima ovalan oblik. Dimenzija duže ose (SZ - JI) je (bila) oko $400 \mathrm{~m}$, a kraće (JZ - SI) oko 300 metara. Južno od polja 1, nizvodno na oko $600 \mathrm{~m}$, formirana je brana od flotacijskog peska. Širina brane 1 iznosi oko $30 \mathrm{~m}$. Na oko $800 \mathrm{~m}$ od brane 1 formirana je nizvodno, druga brana. Između brane 1 i brane 2 deponovana je flotacijska jalovina tako da su najgrublje čestice odvajane i taložene na obalama Borskog potoka i brana, dok je središni deo prostora između brana ispunjen finijom flotacijskom jalovinom. Na prostoru između brane 1 i brane 2 formirano je Polje 2. Teren na Polju 2 izravnan je na približnoj koti $368 \mathrm{~m}$. U planu, Polje 2 ima elipsast oblik. Dimenzija duže ose (SZ - JI) je (bila) oko $800 \mathrm{~m}$, a kraće (JZ - SI) oko 600 metara. Celokupni prostor (Polje 1 i Polje 2) ima elipsast oblik, koji obuhvata povrišinu od oko $1 \mathrm{~km}^{2}$. Tehnogeno ležište bakra Staro flotacijsko jalovište u Boru, nastalo je kao rezultat obogaćivanja rude dobijene eksploatacijom na Starom površinskom kopu i podzemnom eksploatacijom. Dugi niz godina vršeno je odlaganje flotacijske jalovine u vidu mulja, prašine i peska. Flotacijskom koncentracijom rude, usled mineraloško-petroloških karakteristika rude i korisnih minerala, kao i usled nesavršenosti tehnološkog postupka, $85 \%$ bakra izdvaja se u koncentrat, dok se ostatak izdvaja u flotacijsku jalovinu. Slično je i sa drugim korisnim komponentama. Procentualno učešće korisnih komponenti izdvojenih, u koncentrat ili u flotacijsku jalovinu, zavisi od njihovog iskorišćenja primenjenim tehnološkim postupkom obogaćivanja.

Za sam prostor Starog flotacijskog jalovišta u Boru, tektonika nije značajna, jer se praktično radi o savremenim tvorevinama koje nisu bile izložene tektonskim silama koje deluju u geološkom vremenu. Ipak treba dati kratak osvrt na rasednu tektoniku u geogenoj podlozi ležišta. Najmarkantnija struktura, neposrednoj okolini istražnog prostora, je „Borski rased“. Borski rased je u stvari rasedna (razlomna) zona, čija širina dostiže i 30-40 m, sa milonitskom zonom od 4 do $8 \mathrm{~m}$ debljine. Glavni strukturni pravci su, od borskog ležišta prema severu, predstavljeni sistemom manjih subparalelnih raseda duž istočnog oboda borske metalogenetske zone. Morfostrukturnom analizom područja (Petković, 1984), utvrđeno je da se veliki "Borski rased" može pratiti sve do raseda "Veliki Pek". Predstavlja složenu zonu razlamanja formiranu u postrudnom periodu. Strmog je pada $\left(75-80^{\circ}\right)$, prema jugozapadu i ima levo transkurentno do levo reversno kretanje. Ovakve strukture ukazuju na izvesna prerudna kretanja i prostorno su konstatovane samo u istočnom obodu TMK.

\section{PREGLED RANIJE IZVRŠENIH ISTRAŽIVANJA}

Dokazi o rudarskoj aktivnosti na području borske metalogenetske zone potiču iz vremena od pre 6 milenijuma (Rudna Glava), zatim iz staroantičkog i rimskog perioda. Savremenija geološka istraživanja na terenima Istočne Srbije započinju krajem 19. veka, a 1903. godine je u Boru potkopom presečeno rudno telo Čoka Dulkan. Od tada se rudarsko-geološka istraživanja $u$ Borskom rudištu bakra inteziviraju.

Šire područje istražnog prostora Staro Borsko jalovište, je okolina Bora, odnosno područje koje je ranije mahom tretirano kao šira okolina Bora. Geološke podatke o ovom terenu nalazimo u radovima Žujovića (1889, 1893, 1900), Antule (1904), Lazarevića (1909, 1910), Cvijića (1904), V. Petkovića (1935), Ilića, i Simića (1949), Antonijevića (1957, 1959), F. Drovenika i M. Drovenika (1956), M. Drovenika (1953, 1959, 1961, 1966, 1968, 1983), M. Drovenika, I. Antonijevića i dr. (1962, 1967). Istraživanja vezana za istraživanja jalovišta i šljačišta, 
odnosno za njihovo korišćenje kao tehnogenih sirovina, počinju početkom šezdesetih godina prošlog veka i sa prekidima traju do danas. Tek početkom ovoga veka, u uslovima sve manje rudničke, obraća se veća pažnja na jalovišta kao potencijalne prostore za pronalaženje ekonomski interesantnih koncentracija bakra i drugih korisnih komponenti. Tome doprinosi i stalni porast cena bakra i plemenitih metala u poslednje vreme.

U široj okolini istražnog prostora "Staro flotacijsko jalovište" (Polje 1 i Polje 2), na području Rudnog polja Bor, vršena su obimna istraživanja. Istraživanja u posleratnom periodu vršena su od juna 1961. do kraja januara 1962. godine, pri čemu su primenjeni geološki radovi, i rudarski istražni radovi (istražno bušenje). Istražno bušenje vršeno je u periodu od 1961. do 1962 godine. Istražnim bušenjem obuhvaćen je deo istražnog prostora, takozvano Polje 1, pri čemu je izbušeno 87 plitkih bušotina po kvadratnoj mreži 40x40 m. Dužina bušotina bila je $10 \mathrm{~m}$, a samo manji broj je imao dužinu od $30 \mathrm{~m}$. Procenat izvađenog jezgra bio je oko 100\% (Stevanović, 1963). Bušotine su analizirane na bakar, ukupni i oksidni, i sumpor. Analize na prateće korisne i štetne komponente nisu rađene.

Eksploatacija borskog ležišta, od početka prošlog veka, zahvatila je 26 rudnih tela - jamski i površinskim kopom (dobrim delom $\mathrm{u}$ isto vreme). Pri tome je dobijeno ukupno 146.270.000 t rude bakra iz koje je estrakovano 2.437.000 tona metala bakra, $139.140 \mathrm{~kg}$ zlata i $415.000 \mathrm{~kg}$ srebra. Takođe je otkopano i 436.200.000 tona jalovih masa, otkrivke i pratećih stena (Maksimović M., Nikolić K., 2005)

Eksploatacija ležišta bakra, starim površinskim kopom u Boru (slika 3.), a kasnije i podzemnom eksploatacijom, kao i obogaćivanje rude i dobijanje koncentrata u borskoj flotaciji, uslovile su izmene paleoreljefa, smislu degradacije prirodnog reljefa, uz stvaranje uzvišenja od nagomilanih materijala flotacijske jalovine. Metalurška prerada koncentrata uslovila je stvaranje deponija šljake. Najveća količina šljake odložena je na lokalitetu između površinskog kopa rudnog tela „H“ i bivšeg prališta radionice starog površinskog kopa, pa je ova lokacija poznata kao „Depo šljake - 1 .

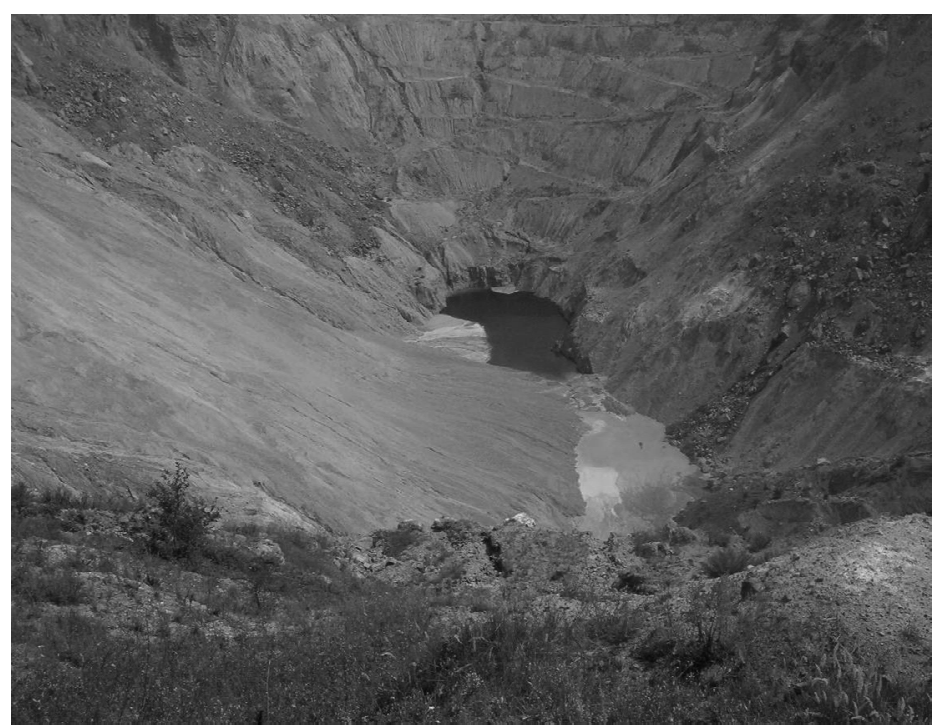

SI. 3. Stari borski površinski kop, Bor (avgust 2005.) 
U zavisnosti od tehnologija koja su bila korišćena u eksploataciji, faze metalurškog procesa topljenja u kojima je nastajala šljaka, kao i samih karakteristika rude, koncentrata bakra i topitelja, stvaran je tehnogeni otpad, veoma različitih - kako fizičkih i mineraloških, tako i hemijskih karakteristika. Sve šljake nastale u različitim vremenskim periodima odlagane su na više lokaliteta, a sa pojedinih lokacija vršena su i premeštanja usled izvođenja rudarskih radova pri otvaranju i proširenju površinskih kopova (stari površinski kop i površinski kop rudnog tela „H“).

\section{PROJEKTNA REŠENJA DETALJNIH PRIMENJENIH GEOLOŠKIH ISTRAŽIVANJA}

$\mathrm{Na}$ osnovu analize i sinteze dosadašnjih istraživanja i literaturnih podataka, definisani su koncepcija i metodologija istraživanja u narednom periodu. Detaljna primenjena geološka istraživanja vršiće se sa ciljem pronalaženja dodatnih količina bakra iz tehnogenog ležišta, radi povećanja mineralno - sirovinske baze RBB-a, a samim tim i povećanje količina rude koja će se preraditi. Detaljna geološka istraživanja na prostoru Starog flotacijskog jalovišta usmerena su na postupno, sistematično i sveobuhvatno istraživanje $\mathrm{i}$ ispitivanje ovog prostora i pronalaženja ekonomski interesantnih količina tehnogene sirovine. Celokupna geološka istraživanja su podređena i prilagođena geološko - metalogenetskim prilikama terena, stepenu njegove istraženosti, aktuelne problematike i cilju istraživanja.

Osnovni cilj je da se izvrše detaljna geološka istraživanja radi utvrđivanja podataka potrebnih za izradu Elaborata o rudnim rezervama, koji je neophodan za buduća rudarska projektovanja, ali i dobijanju relevantnih podataka za rekultivaciju i remedijaciju ovog prostora koji se nalazi u samom gradu Boru. Geološkim istraživanjem $u$ narednom periodu primenile bi se kompleksne metode istraživanja, koje obuhvataju sledeće radove: geodetske radove, geološke radove, istražno bušenje, studijska ispitivanja, laboratorijska i tehnološka ispitivanja u laboratorijskom i poluindustrijskom obimu. Geološko istraživanje biće praćeno geološkim kartiranjem i oprobavanjem jezgra bušotina radi ispitivanja kvaliteta i kvantiteta mineralne sirovine: uzimaće se uzorci za mineraloško-petrološka ispitivanja; vršiće se geomehanička ispitivanja radi sagledavanje mogućnosti eksploatacije mineralne sirovine. Ispitivanje kvaliteta obuhvata uzimanje proba mineralne sirovine za hemijska i tehnološka ispitivanja. Istražnim radovima definisaće se geološka građa i geološke karakteristike istražnog prostora, i potvrditi rezultati ispitivanja kvaliteta mineralne sirovine dobijenih ranijim istražnim radovima.

\section{ZAKLJUČAK}

Predmetni prostor se nalazi se $\mathrm{u}$ gradu Boru, u neposrednoj blizini flotacijskih postrojenja „Borske flotacije“. Na bazi dosadašnjih geoloških istraživanja u pomenutoj zoni, indicirana je mineralizacija bakra, koja bi se realizacijom geoloških radova, istražila do nivoa $\mathrm{B}$ i $\mathrm{C}_{1}$ kategorije rezervi, i utvrdio kvalitet mineralne sirovine, odnosno sadržaj bakra, zlata, srebra i drugih korisnih, ali i štetnih komponenti.

Osnovni cilj geoloških istraživanja, prostora "Staro borsko jalovište", je da se u skladu sa prikupljenim podacima o rezultatima dosadašnjih istraživanja izvrši izbor optimalnih projektnih rešenja (vrsta i obim radova) za predstojeća istraživanja, u cilju pronalaženja rude bakra i pratećih korisnih komponenti, u deponijama tehnogene sirovine. Gustina istražnih radova zavisi od postignutih rezultata, od čega zavisi i nastavak istraživanja. $\mathrm{Na}$ osnovu, studijskih istraživanja, izvršila bi se ocena potencijalnosti istraživanog područja. Realizacijom detaljnih primenjenih istraživanja $\mathrm{u}$ vidu 


\section{LITERATURA}

istražnih radova, očekuje se da se pouzdanije utvrde karakteristike tehnogenog ležišta (obim, razmera, uslovi zaleganja), kvalitet mineralne sirovine, utvrde rezerve do nivoa $\mathrm{B}$ i C1 kategorije. $\mathrm{Na}$ osnovu rezultata istraživanja ocenili bi se geološki, tehničko eksploatacioni, tehnološki, tržišni, regionalni i socijalno - ekonomski faktori i odgovarajući pokazatelji istraživanja.

Ekonomski značaj istraživanja tehnogenih sirovina, na području starog flotacijskog jalovišta u Boru, tržišna vrednost korisnih komponenti koje se mogu dobiti iz njih, povoljni regionalni faktori, zaštita životne sredine kroz kasniju rekultivaciju i remedijaciju istražnog prostora, su svakako direktni razlozi koji opravdavaju izvođenje projektovanih geoloških istraživanja. Geološka istraživanja ovog istražnog prostora i pronalaženje ekonomski interesantnih koncentracija bakra i pratećih minerala (zlata, srebra i molibdena), svakako će naći vrlo značajan odraz u smislu geološke i ekonomske efektivnosti izvedenih geoloških istraživanja.

Zasigurno se može reći da su projektovana geološka istraživanja istražnog prostora "Staro flotacijsko jalovište", u funkciji opštih društveno - ekonomskih kretanja i potreba, kao i dugoročnih planova i razvojnih orjentacija RTB-a, grada Bora i Republike Srbije. S toga se i sa ovog aspekta može zaključiti da je značaj i ekonomska opravdanost projektovanog istraživačkog zadatka nesumnjiva, što je i direktni razlog da se predmetna istraživanja dosledno realizuju.

Dobijeni rezultati detaljnih geoloških istraživanja, sintetizovali bi se kroz izradu Elaborata o izvršenim geološkim istraživanjima i Elaborata o rudnim rezervama. Istraživanja bi pratila izrada odgovarajuće grafičke dokumentacije, periodičnih izveštaja, kao i izrada Elaborata o izvršenim geološkim istraživanjima.
[1] Maksimović M., Nikolić K. i dr.: Elaborat o rezervama ležišta bakra Bor (rudna tela "Brezanik", "Tilva Roš“، i "P2A"), stanje 31.12.2004.-tekstualni deo, Fond stručne dokumentacije, Odeljenje za geologiju IRM Bor; 2005., 144 s.

[2] Maksimović M.: Projekat detaljnih geoloških istraživanja bakra i drugih korisnih komponenti na prostoru Starog flotacijskog jalovišta u Boru (Polje 1 i Polje 2), u 2011/12. godini, Fond stručne dokumentacije Odeljenje za geologiju IRM Bor; 2011., 44 s.

[3] Maksimović M.: Projekat istraživanja i ispitivanja flotacijskih i kopovskih jalovišta Bor, na području neaktivnog ekološkog eksploatacionog polja, vezano za aktivnosti na remedijaciji od strane Svetske banke, Fond stručne dokumentacije Odeljenje za geologiju IRM Bor; 2011., $55 \mathrm{~s}$.

[4] Maksimović M.: Projekat geološkoekološkog istraživanja $\mathrm{i}$ ispitivanja $\mathrm{u}$ okviru ugrožene ekološke zone - Jalovišta u Boru (Brana 2), Fond stručne dokumentacije Odeljenje za geologiju IRM Bor; 2012., $20 \mathrm{~s}$.

[5] Maksimović M.: Elaborat o izvršenim geološkim istraživanjima $i$ ispitivanjima flotacijskih i kopovskih jalovišta Bor, na području neaktivnog ekološkog eksploatacionog polja, vezano za aktivnosti na remedijaciji od strane Svetske banke, u periodu 2011/12. godine, Fond stručne dokumentacije Odeljenje za geologiju IRM Bor; 2012., $83 \mathrm{~s}$.

[6] Maksimović M.: Projekat primenjenih, detaljnih geoloških istraživanja tehnogene mineralne sirovine na prostoru starog flotacijskog jalovišta Bor (Polje 1 i Polje 2), u periodu od 2014. do 2017. godine", Fond stručne dokumen- 
tacije Odeljenje za geologiju IRM Bor; 2014., $55 \mathrm{~s}$.

[7] Stevanović O.: Study of Copper Reserves in the Flotation Tailings, Text Part, Fund Professional Documentation Department of Geology IRM Bor, 1963.,106 s.

[8] M. Maksimović, M. Jovanović, G. Pačkovski, V. Marinković: Preliminarni geološki istražni radovi u cilju upravljanja životnom sredinom na prostoru neaktivnog ekološkog eksploatacionog polja, Mining and Metallurgy Engineering Bor, 2/2014, str. 7-12.

[9] M. Pavlović, N. Vušović, M. Maksimović, R. Rajković: Osnovni principi izrade i korišćenja digitalnog geomodela kod projektovanja površinskog kopa na primeru ležišta kvarcnog peska i peskovite gline „Bošnjane“, Srbija, Mining and Metallurgy Engineering Bor, 2/2014, str. 107-116. 